\title{
Towards Adaptive Spatial Planning for Climate Change: Balancing Between Robustness and Flexibility
}

\author{
Arwin van Buuren*, Peter P.J. Driessen**, Marleen van Rijswick***, Piet \\ Rietveld $^{* * * *}$, Willem Salet***, Tejo Spit****, Geert Teisman* \\ *Erasmus University Rotterdam, Department of Public Administration \\ ${ }^{*}$ Utrecht University, Copernicus Institute of Sustainable Development \\ ${ }^{* *}$ Utrecht University, Department of Law \\ ${ }^{* * * *}$ Free University Amsterdam, Faculty of Economics \\ ${ }^{* * *}$ University of Amsterdam, Department of Geography, Planning and Development Studies \\ ${ }^{* * *}$ Utrecht University, Department of Human Geography and Planning
}

\begin{abstract}
Adaptation to climate change necessitates serious adjustments to the spatial organization of our environment. However, the uncertainties, the controversial character of the climate debate, the variety of climate change consequences and the inherently complex character of climate change puts specific demands on adapting spatial planning to climate change. Due to these characteristics of climate change, climate adaptation demands "adaptive spatial planning". One of the main challenges is to balance between a robust and a flexible approach. On the one hand adaptive spatial planning tries to enable social and economic functions to flourish. On the other hand flexibility is required in finding creative combinations between the fulfillment of climate adaptation and other spatial interests. In this article we reconsider the strategic departure points for spatial planning (norms, values and principles), the interactive organization of planning processes, and the allocation of responsibilities, costs and benefits in planning processes which in our view constitute adaptive spatial planning practices in the context of climate change.
\end{abstract}

\section{Keywords}

climate change; climate adaptation; spatial planning

\section{Introduction}

Climate change poses new and unexpected challenges to our current way of living, working, recreation and transport. On the one hand we have to think 
about changing to a much more sustainable and climate durable way of living by mainstreaming mitigation strategies into our daily practices. That means that citizens, enterprises and governments have to think about more sustainable practices, procedures and investments. There are many examples of mitigation programs with ambitious goals to reduce carbon gases in cities like London, New York, Toronto, Berlin and Rotterdam (see Clinton Climate Initiative-http://www.clintonfoundation.org/).

Although mitigation is necessary to slow down climate change, it is not enough. It is also necessary to adapt our societies to the (potential) impacts of climate change we cannot prevent. Due to changing weather conditions, we have to think about the spatial organization of our society, because existing ways of using our environment are becoming more risky, are no longer desirable or even possible. ${ }^{1}$ While many definitions of adaptation to climate change are in circulation, one of the most commonly used definitions is the IPCC's, which defines adaptation as "the adjustment in natural or human systems in response to actual or expected climatic stimuli or their effects, which moderates harm or exploits beneficial opportunities." Adaptation thus focuses on anticipating climate impacts in three ways: minimizing potential damage; coping with the consequences of impacts; and taking advantage of opportunities. $^{3}$

The spatial impact of climate change and thus the need for adaptation can be substantial. The rise of the sea level can be a serious threat for the urbanized deltas of our world. Long periods of extreme drought pose severe challenges to vital domains such as agriculture and shipping. Heat stress can cause significant numbers of victims in densely populated cities. Extreme wind conditions call for serious investments in air transport planning. ${ }^{4}$ In general there are at least four spatial domains where climate change has an impact:

\footnotetext{
1) European Environment Agency. (2007). Climate change: the cost of inaction and the cost of adaptation. EEA Technical Report No 13 / 2007.

2) IPCC, Climate Change: The Fourth Assessment Report, 2007.

3) C.Termeer, A. Dewulf, H. van Rijswick, A. van Buuren, D. Huitema, S. Meijerink, T. Rayner and M. Wiering, The Regional Governance of Climate Adaptation: A Framework for Developing Legitimate, Effective and Resilient Governance Arrangements, Climate Law I (20II) I-2I.

4) Intergovernmental Panel on Climate Change (200I) Climate Change 200I; impacts, adaptation, and vulnerability, contribution of Working Group II to the Third Assessment Report of the IPCC.
} 
(I) The main water system and fresh water supply;

(2) Agriculture and nature;

(3) The urban environment;

(4) The various networks (infrastructure, energy, transport, IT).

However, the question is whether our current way of organizing spatial planning (in terms of design, decision-making and implementation) enables or supports the realization of climate adaptation. In this paper we explore the challenges climate change poses for the way western societies organize their spatial planning, with a special focus on the implications for the legal principles that structure spatial planning, the governance of actual planning processes and the arrangements to distribute costs and benefits of spatial investments. Spatial planning refers to the strategies and methods used by governmental agencies - sometimes in close cooperation with private actorsto influence the distribution of activities in spaces on various levels. We will analyze both the characteristics of climate change and its consequences on the spatial environment, in order to formulate the demands that climate adaptation makes on the arrangement of spatial planning. These characteristics involve the uncertainty of climate change, the controversy of the urgency to act, the complexity of climate change and the multifaceted character of climate change impacts. They do have consequences for at least three cornerstones of spatial planning which will be analyzed in this paper; the institutional arrangements for planning (the institutional principles and rules of the game), the governance of planning processes (the way in which concrete planning processes are organized) and the role of public-private initiatives and the relevance of financial instruments in order to balance costs and benefits. ${ }^{5} \mathrm{We}$ will conclude this paper by summing up the conditions that are relevant for effectively embedding climate adaptation into spatial planning. To illustrate our main line of argument we frequently refer to the Dutch debate about climate adaptation, the proposals of the Delta Committee ${ }^{6}$ to anticipate on climate change in the water domain, and recent proposals to integrate climate adaptation in the domains of water management, urban planning and nature conservation.

\footnotetext{
5) Willows, R.I. and Connell, R.K. (Eds.). (2003). Climate adaptation: Risk, uncertainty and decision-making. UKCIP Technical Report. UKCIP, Oxford.

6) Delta Committee. (2008). Samen werken met water. Den Haag. ISBN/EAN 978-909023484-7.
} 


\section{The Characteristics of Climate Change}

The issue of adaptation to climate change can be characterized by uncertainty, contentiousness, multiplicity and complexity.

\section{I. Uncertainty}

Although more and more knowledge is being gathered about climate change and its impacts, climate change is surrounded by serious uncertainties. ${ }^{7}$ We know a few things within tolerable degrees of certainty, but we don't know exactly how they are caused or how they will evolve. Other developments we know but we don't know their exact consequences. And, although we don't know it for certain, it is quite conceivable that we are ignorant of some future climate changes and their consequences on, for example, human health, flora and fauna.

This uncertainty poses severe threats to 'the governance of adaptation'. Taking decisions about how to adapt to climate change in the face of uncertainty is very difficult. After all, we don't know whether adaptation is necessary, whether it is enough and whether it does generate the intended results. Uncertainty can be an important obstacle for decision-making and may cause hesitation. ${ }^{8}$ It can also be a reason to build in some margins and to take some additional safety measures. At the same time uncertainty calls for possibilities to reconsider decisions when the situation alters. And above allbecause of the possible disastrous impacts - there is a strong (perceived) need for no- and low-regret measures.

\subsection{Contentiousness}

The uncertainty of climate change and its long-term character are important explanations for the inherent controversial character of many climate adaptation measures. If there was no doubt about the seriousness and urgency of climate change and its consequences, realizing consensus about adaptation measures would be much easier. However, complete certainty (if possible at

\footnotetext{
7) Intergovernmental Panel on Climate Change (200I) Climate Change 200I; impacts, adaptation, and vulnerability, contribution of Working Group II to the Third Assessment Report of the IPCC.

8) Giddens, A. 2009. The politics of climate change. Polity Press: Cambridge.
} 
all) cannot remove the inherent value conflicts that are raised by adaptation measures. After all, adaptation implies the reallocation of scarce means, be they financial, organizational or spatial when, for example, protection against floods in unembanked areas is not longer guaranteed. That means that vested interests-displayed by a specific spatial allocation of functions-can be harmed by adaptation measures. Furthermore, absolute certainty about climate change and its effects does not take away differences of interpretation of the seriousness of these impacts, or differences in opinion on whether (governmental) action is necessary.

\subsection{Multiplicity}

Climate change is a multi-faceted phenomenon and its consequences are heterogeneous. The consequences of climate change depend heavily on the specific geographical context in which they become manifest. On the one hand climate change causes macro-effects with regard to sea-level rise and a general rise of temperature (global warming). On the other hand climate effects like wind disturbance, drought or heat stress can be very local or regional, due to the specific spatial circumstances. Moreover, some developments within our climate can have rather opposite effects. The agricultural sector in the Netherlands for instance could benefit from a rise in temperature and changing climate conditions in other countries, but at the same time the sector will have to cope with other types of problems like salt-water intrusion, peat oxidation and freshwater shortage. Both drying out and water nuisance due to extreme rainfall are two sides of the same phenomenon.

However, the multi-faceted character of climate change also enables (multifunctional) adaptation strategies with a clear win-win character. Heat stress in densely populated areas can be diminished by realizing more water retention capacity or more green areas. Broadening the coastal zone can create lots of opportunities for recreation, project development and nature development.

\subsection{Complexity}

The aforementioned characteristics contribute to the complexity of climate change. With this characteristic we want to point to the non-linear and erratic nature of climate change and the non-linear feedback loops caused by climate change. However the complexity of climate change also has to do with the interconnectivity of this phenomenon with other domains and functions. 
Adaptation measures cannot be implemented as single-purpose strategies that are realized in a vacuum, but have to be aligned to other developments to be effective. In addition there are sometimes complex relations between mitigation and adaptation strategies. A final complex characteristic of climate change and its consequences is the impact of local initial conditions: the consequences of one specific aspect of climate change can be highly different in various local settings due to their specific characteristics. ${ }^{?}$

\section{Towards Adaptive Spatial Planning}

Spatial planning has to play a vital role in implementing adaptation measures and in safeguarding the climate robustness of spatial developments. The four characteristics mentioned above call for an adaptive approach in which learning, experimentation, dialogue and flexibility are central. In such an approach much emphasis is given to building consensus with all actors involved, to deal with the complex and controversial character of climate change. This approach of governance is worked out in many studies. ${ }^{10}$ Much attention is given to developing flexible and inclusive co-operation between public, private and societal actors. ${ }^{11}$ In addition, insight is given into the importance

9) Willows, R.I. and Connell, R.K. (Eds.). (2003). Climate adaptation: Risk, uncertainty and decision-making. UKCIP Technical Report. UKCIP, Oxford.

10) Folke, C., T. Hahn, P. Olsson and J. Norberg (2005) Adaptive governance of social-ecological systems, Annual Review or Environment and Resource, 30: 44I-473; Giddens, A. 2009. The politics of climate change. Polity Press: Cambridge; Huitema, D., E. Mostert, W. Egas, S. Moellenkamp, C. Pahl-Wostl, and R. Yalcin. 2009. Adaptive water governance: assessing the institutional prescriptions of adaptive (co-)management from a governance perspective and defining a research agenda. Ecology and Society I4(I): 26. [online] URL: http://www.ecologyandsociety.org/voli4/ issi/art26/. Ward, P.J., P. Pauw, A. Van Buuren, M.A. Marfai. 20I2. A tale of two cities: Governance lessons for flood risk management in a time of climate change-the cases of Jakarta and Rotterdam. Environmental Politics (online first, doi:10.1080/09644016.2012.683155).

11) Brunner, R.D., T.A. Steelman, L. Coe-Juell, C.M. Cromley, C.M. Edwards and D.W. Tucker (2005) Adaptive governance; integrating science, policy, and decision-making, New York: Columbia University Press; Johnson, B.L. (1999) Introduction to the special feature; adaptive management—scientifically sound, socially challenged? Conservation Ecology, 3(I) [online] URL: http:// www.consecol.org/vol3/issi/artio/; Pahl-Wostl, C. (2006) Transitions towards adaptive management of water facing climate and global change, Water Resources Management, 2I(I): 49-62; Raadgever, G.T., E. Mostert, N. Kranz, E. Interwies and J.G. Timmermans (2008) Assessing management regimes in transboundary River basins; do they support adaptive management, Ecology and Society, I3(I) http://www.ecologyandsociety.org/volı//issı/artı4/. 
of facilitating bottom-up processes of self organization ${ }^{12}$ which acknowledge the multiplicity of climate change and its consequences and which are aimed at increasing resilience to climate-induced disturbances of our social systems.

Because we don't know exactly what constitutes the problem of climate change and its consequences, many authors stress that adaptive spatial planning should invest in experiments and pilots to find out which solutions are valuable and effective. ${ }^{13}$ These trajectories are based upon incremental steps that do not depart from a fixed end goal, but gradually explore possibilities and opportunities. They are flexible and adjustable and thus able to adapt to unexpected feedback loops. ${ }^{14}$

However, the uncertainty about climate change and its consequences asks not only for flexibility and adjustability, but also for robust and sound provisions that safeguard the sustainability and long-term profitability of spatial investments. For instance, to guarantee the sustainability of economic investments, safety norms against floods have to be robust and unequivocal. Perhaps even more important is the need for legal certainty regarding rights and duties, and a clear partition of responsibilities between several public partners and between public and private partners. They are necessary to assure legitimate climate adaptation policies. That is, for example, the reason that Dutch water law has legally binding safety norms that are related to decisions based on

12) Folke, C., S. Carpenter, T. Elmqvist, L. Gunderson, C.S. Holling and B. Walker (2002) Resilience and sustainable development; building adaptive capacity in a world of transformation, Scientific background paper on resilience for the process of The World Summit on Sustainable Development on behalf of The Environmental Advisory Council to the Swedish Government; High, C. and M. Pelling (2003) Understanding adaptive capacity to rapid climate change; theories of social and organizational learning, Rapid Climate Change Project Working Paper I.

13) Berkes, F. and D. Jolly (200I) Adapting to climate change; social-ecological resilience in a Canadian Western Arctic community, Conservation Ecology 5(2): I8. [online] URL: http:// www.consecol.org/vol//iss2/arti8/; Berkhout, F., J. Hertin and D.M. Gann (2004) Learning to adapt; organisational adaptation to climate change impacts, Tyndall Centre for Climate Change Research, Working Paper no. 47; Brunner, R.D., T.A. Steelman, L. Coe-Juell, C.M. Cromley, C.M. Edwards and D.W. Tucker (2005) Adaptive governance; integrating science, policy, and decision-making, New York: Columbia University Press; Folke, C., T. Hahn, P. Olsson and J. Norberg (2005) Adaptive governance of social-ecological systems, Annual Review or Environment and Resources, 30: 44I-473; Stubbs, M. and M. Lemon (200I) Learning to network and networking to learn; facilitating the process of adaptive management in a local response to the UK's National Air Quality Strategy, Environmental Management, 27(3): 32I-334.

14) Adger, W.N., N.W. Arnell and E.L. Tompkins (2005) Successful adaptation to climate change across scales, Global Environmental Change, I5: 77-86. 
the Spatial Planning Act. Planning authorities and water authorities have a shared responsibility, which is elaborated in cooperation and coordination obligations.

In the next table we summarize both sides of the coin of the governance of adaptation, where the left column presents the demands for decisive and sound governmental action based upon governmental capacity, and the right column appeals to self-organizing, bottom-up strategies aimed at maximizing flexibility and openness. These two sides of the governance of adaptation are ultimately contradictory, full of tensions and dilemmas.

These dual requirements can be found for instance in the field of regional water management, where there are interesting tensions between strict water safety levels and bottom-up processes to align water management with other spatial ambitions. The same tension can be observed in the report of the Dutch Delta Committee where it at the same time incites the forming of a Delta Law, a National Delta Program, a Delta Fund and a Delta Commissioner with powers to bring together all parties involved, and also asks for regional actors

Table 1. Demands on spatial planning

\begin{tabular}{lcc}
\hline Characteristic & Demand for robustness & Demand for flexibility \\
\hline Uncertainty & Asks for solid and judicial & Asks for possibilities to adjust \\
& $\begin{array}{l}\text { guarantees for safety, } \\
\text { durability and liability. }\end{array}$ & $\begin{array}{c}\text { policy strategies, experimental } \\
\text { policy-designs, learning by } \\
\text { doing. }\end{array}$ \\
& Asks for authoritative and & Asks for provisions to facilitate \\
Contentiousness & decisive action by democratic & joint problem-solving, \\
& legitimized authorities & deliberation and collaborative \\
& and clear, transparent & dialogues. \\
decision rules. & \\
Multiplicity & Asks for unambiguous policy & Asks for room for polycentrism, \\
& criteria to enable effective & custom-made solutions, issue \\
& planning choices. & linkages and bottom-up \\
& initiatives. \\
Complexity & Asks for institutional provisions & Asks for experimental policy \\
& that facilitate complex & designs, mainstreaming \\
& governance networks to & climate with other \\
& realize collective action. & spatial activities and \\
& & experimental planning \\
& & strategies. \\
& &
\end{tabular}


to develop regional 'sub-delta programs' with much room for stakeholder involvement and flexibility. ${ }^{15}$

However, the question of how to balance adaptive spatial planning between flexibility and robustness cannot be answered when we have not answered the more fundamental question of what the role of government is in spatial planning, and the way in which government formulates the legal departure points for adaptive spatial planning. ${ }^{16}$ These choices determine the space of opportunities to organize adaptive planning processes.

Complementary to the question of which institutional norms and planning arrangements are appropriate for governments dealing with climate adaptation, is the question: What is an efficient allocation of responsibilities and distribution of costs and obligations in planning processes? Spatial planning is always a co-evolutionary process of public regulation and private investment choices. We thus have to think about criteria and mechanisms that enable an efficient allocation of public and private dedication to adaptation challenges, and facilitate a debate about the allocation of costs and benefits of adaptation measures.

In our view three elements of adaptive spatial planning deserve special attention. First, we have to reconsider the institutional context of (adaptive) spatial planning. This is a matter of institutional design and answers the question of what the role of government is in adaptation and how this role is institutionally shaped. What are the institutional norms and principles that have to be adopted to provoke and facilitate adaptive spatial planning? The institutional design of adaptive spatial planning can be seen as the framework within which planning processes evolve. Secondly, we have to think about the organization of concrete planning processes. The way in which planning processes are actually managed has to balance between the demands for robustness and flexibility. Finally, to make efficient choices about climate adaptation and to distribute the workload between public and private partners we have to investigate the principles that can be used to allocate responsibilities and costs to safeguard the economic rationality of the governance of adaptation.

\footnotetext{
15) Delta Committee. (2008). Samen werken met water. Den Haag. ISBN/EAN 978-909023484-7.

16) P.P.J. Driessen and H.F.M.W, van Rijswick (20II). Normative aspects of climate adaptation policies, Climate Law, vol. 2(4), pp. 559-58I.
} 


\section{The Institutional Framework for Climate Adaptation}

\section{I. Flexible and Legitimate}

The first way to guide the myriad of adaptive spatial planning measures is via the use of general legal principles that fit into and build upon socially accepted values. ${ }^{17}$ Actually, practices of adaptive governance tend to neglect the legal context as far as possible, and move away from the extremely specified legalism towards informal strategies of policy making, getting legal arrangements back as a boomerang at the end of the process. ${ }^{18}$ In particular, the abundant flow of detailed input norms on social action frustrates adaptive behavior instead of stimulating creative response, and provokes governance practices in the legal 'twilight zone'. ${ }^{19}$ In short, a plea for a governance approach is not sufficient. It should be combined with an approach that guarantees at least a certain minimum level of protection for the most basic needs of society, which is based on principles and the rule of law, and which should ensure legitimate adaptive planning. ${ }^{20}$ Detailed prescriptions are not necessary. We argue instead that legislation has to return to the old principles of generality and durability in order to stimulate creative and contextualized response to the changing conditions of climate. An interesting example is the Dutch 'Space for the River' program, aimed at realizing enough river basin capacity to accommodate high river discharges, by setting legally binding safety standards that have to be met

17) C.Termeer, A. Dewulf, H. van Rijswick, A. van Buuren, D. Huitema, S. Meijerink, T. Rayner and M. Wiering, The Regional Governance of Climate Adaptation: A Framework for Developing Legitimate, Effective and Resilient Governance Arrangements, Climate Law I (20II) I-2I; P.P.J. Driessen and H.F.M.W. van Rijswick, Normative Aspects of Climate Adaptation Policies, Climate Law, 2 (20II), p. I-23.

18) Fleurke, F. and N. Koeman (2005) The impact of the EU Air Quality Standards on the planning and authorisation of large-scale infrastructure projects in the Netherlands, Journal of European Environmental and Planning Law, 5: 375-383.

19) Burca, G. de \& Scott, J. (eds.) 200o. Constitutional change in the EU. From uniformity to flexibility?, Oxford and Portland, Oregon: Hart Publishing; Scott, J. and D.M. Trubeck (2002) Mind the gap; law and new approaches to governance in the European Union, European Law Journal, 8: I-I8; Pallemaerts, M. et al. (2006) Drowning in process? The implementation of the EU's 6th Environmental Action Programme, London: IEEP; European Commission (200I) European Governance, COM 200 .

20) P.P.J. Driessen and H.F.M.W. van Rijswick, Normative Aspects of Climate Adaptation Policies, Climate Law, 2 (20II), p. I-23; Rijswick, H.F.M.W. van (2008) Moving water and the law; on the distribution of water rights and water duties within river basins in European and Dutch water law, Groningen: Europa Law Publishing. 
in a prescribed time. Within this legal framework the various regions were more or less free in how they realized the required retention capacity.

\subsection{Public and Private}

Before looking into the content of such legal arrangements, a preliminary question has to be discussed. Is adaptation to climate change a role or task for the government and if yes, how far? Most adaptive behavior can be seen as a responsibility of individuals. In that case there can be a supporting role for the government. Besides stimulating the desired behavior, some boundaries have to be set. They follow from the rule of law, the concept of good governance, the legitimacy of norms and standards and life in a democratic society that respects the rights of individuals. Furthermore, the level of protection the government promised its citizens should be as clear as possible, because this leads to legal certainty, and individuals know from which point onwards they have to take their own responsibilities. In the discussion on climate adaptation, this question is hardly on the agenda. If there is a role for the government, the question arises as to which interests the government wants to protect, and how far. Taking water law as an example, general accepted interests are sufficient and clean drinking water, protection against flooding, clean and sufficient water for economic and agricultural activities, and of course water for the benefit of nature. A minimum level of protection is often guaranteed by governments, and legal norms and procedures that guarantee public participation and access to justice are necessary to protect these interests. ${ }^{21}$ However it is not necessary to use very detailed and technical norms at the end of the legal chain of regulation. Prescribing the goals and objectives in a more normative or even quantitative way could be sufficient, if necessary further elaborated in more quantitative safety or quality standards, but only if adequate and effective legal

\footnotetext{
21) H. Smets (ed.), The right to safe drinking water and sanitation in Europe/Le droit à l'eau potable et à assainnissement, sa mise en oeuvre en Europe, Academie de l' eau, France, 20II; F. Sultana and A. Loftus (eds.), The Right to Water: Politics, Governance and Social Struggles, Earthscan, London, 20II; Rijswick, H.F.M.W. van. 2009. Interaction between European and Dutch Water Law, in: S. Reinhard and H. Folmer (eds.), Water Policy in the Netherlands, Integrated Management in a Densely Populated Delta, Issues in water resource policy RFF (Resources for the Future) Press, Washington, DC, USA, ISBN 978-I-9331I5-73-3, 2009, p. 204-224; Larmuseau, I. (ed.) (2008) Constitutional rights to an ecologically balanced environment, Vlaamse Vereniging voor Omgevingsrecht; Verschuuren, J. (1995). The constitutional right to environmental protection, Revue Juridique de l'Environnement, 340.
} 
protection and access to justice is assured. When using generic principles, they should have legal meaning before they can function as an alternative to strict technical and detailed requirements which leave little room for flexibility, innovative solutions and dealing with uncertainties. To realize more multifunctional flood risk measures along the sea and river coasts (which is quite urgent in the densely populated Dutch regions) it is important that the norms for safety are focused more upon which level of safety has to be safeguarded, and less on the question of how this (technically) has to be realized.

\subsection{Guiding Principles}

Leading principles that can be of great assistance in adaptive planning can follow from international, European or national law. Most important is the lex specialis regime of the United Nations Convention on Climate Change (UNCCC) and its principles of equity, solidarity, precaution, sustainability and good neighbourliness. Often principles can be derived from more than one legal source, for example general international law, international water law, or conventions that offer more procedural principles like the Arhus convention. There is no special international or European regime that provides guiding principles in the field of spatial planning. That is the reason we use principles from several regimes that may be able to guide spatial planning decisions in an adaptive way. Examples are the principle of equitable and reasonable utilization of natural resources and the sustainability principle: do not shift problems towards others, neither in time nor in place. Furthermore, more procedural principles like the exchange of information, the principle to cooperate on the basis of equality, territorial integrity, mutual benefit and good faith as well as access to information and access to justice, play a crucial role in the protection of the above-mentioned interests.

\subsection{Balancing Between Principles}

In the field of adaptation to climate change and planning four principles must be mentioned in particular: the precautionary principle combined with planning based on prevention of negative climate impacts, the proportionality principle and the cost recovery principle, which includes the polluter pays principle. Adaptation to climate change often requires measures taken by the government, besides of course the personal responsibility of citizens to take the necessary measures. Action by the government has to balance between 
"doing enough", taking the precautionary principle and the prevention principle as leading principles, "not overdoing", by taking into account the proportionality principle and finally "internalize the costs" of the measures taken by using the cost recovery principle, which includes the polluter pays principle as a guideline.

The precautionary principle can be foremost in the way we have to deal with uncertainties. ${ }^{22}$ The principle can be used in several ways. The more traditional and conservative interpretation means that no activities can take place unless it is absolutely clear that no harm will be caused. However it can also be used in a more adaptive way. Then it leads to the question of who bears the risk if serious harm occurs. Leaving room for individual activities with no more governmental regulation than strictly necessary implies that the risk will be laid fully upon those who want to undertake activities. This is also one of the important prescriptions of the Dutch Delta Committee with regard to developments in climate-sensitive areas. The proportionality principle and the cost recovery principle are also highly applicable to adaptive spatial planning. The government should not overact in its planning ambitions, and only undertake measures necessary to protect the above-mentioned interests. The cost recovery principle forces consideration of the financial consequences of activities, whether they are undertaken by the government or private parties, and asks if all interests are balanced and divided in a fair and just way.

\section{The Organization and Arrangements for Concrete Planning Processes}

Within the legal and institutional framework as described above, the actual planning processes have to be organized, aimed at finding broadly shared visions, designs and development paths for the spatial arrangement of specific areas. Two requirements must be met to implement climate adaptation in concrete practices of spatial planning:

\footnotetext{
22) See Article 3 EU Treaty; Communication from the Commission of 2 February 2000 on the precautionary principle; Nicolas Sadeleer (ed.), Implementing the precautionary principle: approaches from the Nordic countries, EU and USA (2007); Arie Trouwborst, Precautionary Rights and Duties of States (2006); Wybe Th. Douma, The Precautionary principle: Its application in International, European and Dutch Law (2004); Arie Trouwborst, Evolution and Status of the Precautionary Principle (2002); European Environmental Agency, Late lessons from early warnings: the precautionary principle I896-2000, EEA 2002.
} 
I. decisions about the actual allocation of spatial functions must be compatible with the presumed demands rising from climate change;

2. decision-making about adaptation measures must be flexible enough to connect them to other agendas and ambitions.

In other words: the concrete interventions with regard to the governance of adaptation are on the one hand robust enough to react decisively and accurately to serious climate challenges. On the other hand these interventions must be flexible enough to enable tailor-made interventions and creative innovations to achieve adaptation solutions that generate added value, and meet the ambitions of the various stakeholders. Both categories of interventions are necessary to realize climate adaptation: planning processes have to be both enforcing and enabling. ${ }^{23}$ In table 2 we summarize the two categories of

Table 2. Interventions constituting the governance of adaptation

\begin{tabular}{|c|c|c|}
\hline $\begin{array}{l}\text { Departing point } \\
\text { for planning }\end{array}$ & $\begin{array}{l}\text { Intervention aimed at } \\
\text { stability and robustness }\end{array}$ & $\begin{array}{l}\text { Intervention aimed at } \\
\text { flexibility and resilience }\end{array}$ \\
\hline Processes & $\begin{array}{l}\text { Application of project methods } \\
\text { and procedures to realize } \\
\text { decisions within a reasonable } \\
\text { timeframe. }\end{array}$ & $\begin{array}{l}\text { Application of process } \\
\text { methods aimed at realizing } \\
\text { support and enrichment, } \\
\text { based on goal-seeking and } \\
\text { exploration. }\end{array}$ \\
\hline Content & $\begin{array}{l}\text { Formulation of general } \\
\text { principles, rules, directives } \\
\text { and norms which are } \\
\text { broadly applicable. }\end{array}$ & $\begin{array}{l}\text { Learning by doing, political } \\
\text { agendas as invitation for other } \\
\text { actors to connect their own } \\
\text { agenda to the official one. }\end{array}$ \\
\hline $\begin{array}{l}\text { Organizational } \\
\text { arrangements }\end{array}$ & $\begin{array}{l}\text { Development of general } \\
\text { guarantees, rules of the } \\
\text { game and allocation of } \\
\text { responsibilities. }\end{array}$ & $\begin{array}{l}\text { Developing flexible and adaptive } \\
\text { arrangements which enable } \\
\text { collaboration and joint } \\
\text { problem-solving. }\end{array}$ \\
\hline $\begin{array}{l}\text { Area of } \\
\text { application }\end{array}$ & $\begin{array}{l}\text { Climate change with large, } \\
\text { radical and negative impacts: } \\
\text { 1. safeguarding vital societal } \\
\text { functions } \\
\text { 2. guaranteeing elementary } \\
\text { services. }\end{array}$ & $\begin{array}{l}\text { Climate change with small, } \\
\text { uncertain or ambiguous } \\
\text { consequences: } \\
\text { 1. no-regret measures } \\
\text { 2. aligning climate adaptation } \\
\text { with other spatial ambitions. }\end{array}$ \\
\hline
\end{tabular}

23) Bulkeley, H. (2000) Discourse coalitions and the Australian climate change policy network, Environment and Planning C, I8: 727-748. 
interventions by making a distinction between process interventions, substantive interventions and organizational interventions. ${ }^{24}$

With a couple of empirical examples we can illustrate the working of these interventions in the practice of spatial planning.

\section{I. Processes}

To ensure the climate robustness of spatial investments various instruments are currently being developed which can have decisive influence on the course and content of planning processes. For example, the Dutch government has introduced the so-called Water Assessment in the Spatial Planning Act, to force municipalities to take into account the consequences of new spatial developments, for example the consequences for water retention possibilities. The Water Boards must give advice on the effects on the water system. More in general, fixed procedures like Environmental Impact Assessments, Habitat Tests or Climate Assessments can help to structure decision-making processes and ensure the quality of their outcomes. ${ }^{25}$

However, the problem with fixed procedures is their limited flexibility and possibility of fitting into the specific circumstances of a unique decisionmaking process. Furthermore, the criteria used to assess the quality of policy alternatives are not fixed and indisputable. Therefore, we are also witnessing a search for more flexible and moldable process arrangements, which enable the deliberate balancing of the necessity of climate adaptation on the one hand with the solution of urgent spatial problems on the other. Regional and local governments are increasingly working together in participatory planning processes. A concrete example can be found in several 'hot-spots' (e.g. vulnerable areas) in the Netherlands. One example is the Haaglanden region, where there are intensive greenhouse concentrations. At the same time the shortage of retention capacity in this densely populated area is increasingly becoming a problem due to the increase in rainfall. In this region several pilot projects have been started, aimed at facilitating a bottom-up search process with a variety of public, private and societal actors, towards sustainable combinations

\footnotetext{
24) Koppenjan, J.F.M. \& Klijn, E-H. 2004. Managing uncertainties in networks. Routledge: London.

25) Bohensky, E. and T. Lynam (2005) Evaluating responses in complex adaptive systems; insights on water management from the Southern African Millennium Ecosystem Assessment, Ecology and Society, Iо(I): II; Loë, R. de, R. Kreutzwiser and L. Moraru (200I) Adaptation options for the near term; climate change and the Canadian water sector, Global Environmental Change, II(3): 23I-245.
} 
of spatial ambitions with the need for adaptation. Various technical innovations are being explored, which may be able to bridge the conflicting ambitions of local entrepreneurs and regional water authorities. The fact that the Dutch Water Act recently distributed the responsibilities between public and private parties in a rather clear way, ${ }^{26}$ has further stimulated parties to find solutions that are profitable for all.

The literature about adaptive management contains many insights into the organization of adaptive, flexible policy processes meant to facilitate a joint search towards broadly shared and accepted solutions. ${ }^{27}$ These processes are aimed at stimulating local and bottom-up processes of self-organization and assume that national policy processes are susceptible for their input. ${ }^{28}$

The uncertainty and multiplicity of climate change put high demands on the organization of planning processes. In fact, these characteristics presuppose that planning processes are organized as collective learning and experimental processes. ${ }^{29}$ The main challenge for the governance of adaptation lies

26) The first and most important responsibility is that of the private owner himself to deal with water nuisance on his private property. Secondly it is the responsibility of the municipality to deal with a surplus of water within built up areas. The regional water authorities have to deal with sufficient storage capacity in the water system, and finally the creation of water retention areas is a shared responsibility for municipalities (spatial planning) and water authorities (water management).

27) Brunner, R.D., T.A. Steelman, L. Coe-Juell, C.M. Cromley, C.M. Edwards and D.W. Tucker (2005) Adaptive governance; integrating science, policy, and decision-making, New York: Columbia University Press; Johnson, B.L. (1999) Introduction to the special feature; adaptive management—scientifically sound, socially challenged? Conservation Ecology, 3 (I) [online] URL: http:// www.consecol.org/vol3/issI/artio/; Pahl-Wostl, C. (2006) Transitions towards adaptive management of water facing climate and global change, Water Resources Management, 2I(I): 49-62; Raadgever, G.T., E. Mostert, N. Kranz, E. Interwies and J.G. Timmermans (2008) Assessing management regimes in transboundary River basins; do they support adaptive management, Ecology and Society, I3(I) [online] URL: http://www.ecologyandsociety.org/volı/issI/artII/.

28) Huitema, D., E. Mostert, W. Egas, S. Moellenkamp, C. Pahl-Wostl, and R. Yalcin. 2009. Adaptive water governance: assessing the institutional prescriptions of adaptive (co-)management from a governance perspective and defining a research agenda. Ecology and Society I4(I): 26. [online] URL: http://www.ecologyandsociety.org/voli4/issI/art26/.

29) Berkes, F. and D. Jolly (200I) Adapting to climate change; social-ecological resilience in a Canadian Western Arctic community, Conservation Ecology 5(2): I8. [online] URL: http://www. consecol.org/vols/iss2/arti8/; Berkhout, F., J. Hertin and D.M. Gann (2004) Learning to adapt; organisational adaptation to climate change impacts, Tyndall Centre for Climate Change Research, Working Paper no. 47; Brunner, R.D., T.A. Steelman, L. Coe-Juell, C.M. Cromley, C.M. Edwards and D.W. Tucker (2005) Adaptive governance; integrating science, policy, and decision making, New York: Columbia University Press; Folke, C., S. Carpenter, T. Elmqvist, L. Gunderson, C.S. Holling and B. Walker (2002) Resilience and sustainable development; 
in finding ways to develop planning processes which safeguard the climate robustness of planning decisions and at the same time create opportunities to make innovative combinations of ambitions which serve a multiplicity of societal, public and private agendas.

\subsection{Content}

Important Dutch policy programs aimed at enhancing defense against river floods and sea floods were 'Space for the River' and 'Weak Connections' (along the Dutch coastline). These two programs can be characterized by their clear ambitions with regard to climate adaptation. A clear water safety norm was formulated for river safety. In addition, the total amount of available funding was given, as well as the timeframe within which the measures had to be realized. However, the way in which this norm has to be realized was left for the regional and local governments to decide. Many projects derived from this program show a creative balance between a variety of ambitions, including water safety, recreation, nature development, housing and economy. This flexibility of planning norms and rules is especially necessary in a situation of uncertainty and complexity. ${ }^{30}$

building adaptive capacity in a world of transformation, Scientific background paper on resilience for the process of The World Summit on Sustainable Development on behalf of The Environmental Advisory Council to the Swedish Government; Folke, C., T. Hahn, P. Olsson and J. Norberg (2005) Adaptive governance of social-ecological systems, Annual Review or Environment and Resources, 30: 441-473; High, C. and M. Pelling (2003) Understanding adaptive capacity to rapid climate change; theories of social and organizational learning, Rapid Climate Change Project Working Paper 1; Johnson, B.L. (1999) Introduction to the special feature; adaptive management-scientifically sound, socially challenged? Conservation Ecology, 3(1) [online] URL: http://www.consecol.org/vol3/iss1/art10/; Pahl-Wostl, C. (2006) Transitions towards adaptive management of water facing climate and global change, Water Resources Management, 21(1): 49-62; Raadgever, G.T., E. Mostert, N. Kranz, E. Interwies and J.G. Timmermans (2008) Assessing management regimes in transboundary River basins; do they support adaptive management, Ecology and Society, 13(1) [online] URL: http://www .ecologyandsociety.org/vol13/iss1/art14/; Stubbs, M. and M. Lemon (2001) Learning to network and networking to learn; facilitating the process of adaptive management in a local response to the UK's National Air Quality Strategy, Environmental Management, 27(3): 321-334.

30) Bohensky, E. and T. Lynam (2005) Evaluating responses in complex adaptive systems; insights on water management from the Southern African Millennium Ecosystem Assessment, Ecology and Society, Io(I) [online] URL: http://www.ecologyandsociety.org/volıo/issI/artiI/: II; Easterling, W., B. Hurd and J. Smith (2004) Coping with global climate change; the role of adaptation in the United States, Pew Center on Global Climate Change; Loë, R. de, R. Kreutzwiser and L. Moraru (200I) Adaptation options for the near term; climate change and the Canadian water sector, Global Environmental Change, II(3): 23I-245. 
The ambitions with regard to climate adaptation are relatively clear and stable (a clear protection level, fixed legal safety standards for example) but they also give room to actors to realize spatial investments that are climate robust and fit with their own ambitions. ${ }^{31}$ In the Dutch context there are, for example, experiments with multifunctional land-use and temporal planning.

Norms and rules in the context of spatial planning can be interpreted as open invitations; a call for other actors to link their own agendas to the adaptation challenge. In this respect we can speak of 'invitational planning.' ${ }^{32}$ A clear example of this approach can be seen in the Dutch program 'Weak Links', to strengthen a couple of coastal zones, where the provincial government was asked to develop-together with relevant stakeholders-proposals to integrate safety measures with investments in nature development, recreation and other spatial functions.

Climate change asks for fixed and stringent norms with regard to minimum levels of safety because they are necessary for the trust that citizens and investors have in the long-term tenability of their investments. In this respect, the Dutch Delta Committee is proposing to raise the safety norms tenfold and to define clear norms for unembanked areas. To safeguard the core qualities and functions of our spatial environment, minimum levels and conditions have to be formulated with regard to safety, quality and robustness. In the light of climate change, existing assessment criteria can be complemented by new criteria that fit into the challenges of climate adaptation.

At the same time these policies, rules and norms have to be flexible and adjustable. That means that planning processes have to have 'signposts': explicit moments or phases in which the current goals and ambitions are

31) Easterling, W., B. Hurd and J. Smith (2004) Coping with global climate change; the role of adaptation in the United States, Pew Center on Global Climate Change; Intergovernmental Panel on Climate Change (200I) Climate Change 200I; impacts, adaptation, and vulnerability, contribution of Working Group II to the Third Assessment Report of the IPCC; Scheraga, J.D. and A.E. Grambsch (1998) Risks, opportunities, and adaptation to climate change, Climate Research, IO: $85-95$.

32) Bohensky, E. and T. Lynam (2005) Evaluating responses in complex adaptive systems; insights on water management from the Southern African Millennium Ecosystem Assessment, Ecology and Society, IO(I): II [online] URL: http://www.ecologyandsociety.org/volio/issi/artII/; Fankhauser, S., J.B. Smith and R.S.J. Tol (1999) Weathering climate change; some simple rules to guide adaptation decisions, Ecological Economics, 30(I): 67-78; Intergovernmental Panel on Climate Change (200I) Climate Change 200I; impacts, adaptation, and vulnerability, contribution of Working Group II to the Third Assessment Report of the IPCC; Scheraga, J.D. and A.E. Grambsch (1998) Risks, opportunities, and adaptation to climate change, Climate Research, Io: $85-95$. 
evaluated and eventually adjusted to new insights into the impacts of climate change. Another instrument for flexibility is 'portfolio planning'; various alternative spatial plans are developed and the option that fits best into the most actual calculations can be chosen. ${ }^{33}$ A learning attitude is necessary to discover the effective adaptation strategies for dealing with the huge uncertainty and complexity of climate change.

\subsection{Organizational Arrangements}

The governance of adaptation also needs organizational arrangements that are able to deal with the characteristics of climate change. Departing from the logic of order, institutional arrangements are needed to allocate responsibilities and competences necessary to ensure decisive action when required. Due to the fact that climate change does not respect the boundaries of administrative jurisdictions, the governance of adaptation requires arrangements that enable concerted action by various authorities. Current institutional arrangements are frequently fragmented and confined to specific domains, which hinder and frustrate the governance of adaptation. ${ }^{34}$ Integrative arrangements can be temporal or structural and enable mutually adjusted planning efforts. On the other hand organizational arrangements have to be flexible and have to enable emerging collaborative processes with unpredictable outcomes. ${ }^{35}$

33) Bohensky, E. and T. Lynam (2005) Evaluating responses in complex adaptive systems; insights on water management from the Southern African Millennium Ecosystem Assessment, Ecology and Society, IO(I): II; Easterling, W., B. Hurd and J. Smith (2004) Coping with global climate change; the role of adaptation in the United States, Pew Center on Global Climate Change.

34) Adger, W.N. (2003) Social capital, collective action and adaptation to climate change, Economic Geography, 79(4): 387-404; Adger, W.N., N.W. Arnell and E.L. Tompkins (2005) Successful adaptation to climate change across scales, Global Environmental Change, 15: 77-86; Gunderson, L. (1999) Resilience, flexibility and adaptive management; antidotes for spurious certitude?, Conservation Ecology, 3(I) [online] URL: http://www.consecol.org/vol3/isst/art7/; Handmer, J.W., S. Dovers and T.E. Downing (1999) Societal vulnerability to climate change and variability, Mitigation and Adaptation Strategies for Global Change, 4(3-4); Olsson, P., L.H. Gunderson, S.R. Carpenter, P. Ryan, L. Lebel, C. Folke and C.S. Holling (2006) Shooting the rapids; navigating transitions to adaptive governance of social-ecological systems, Ecology and Society II(I) [online]: http://www.ecologyandsociety.org/volıI/issı/artı8/: I8; Yamin, F., A. Rahman and S. Hup (2005) Vulnerability, adaptation and climate disasters; a conceptual overview, IDS Bulletin, 36(4).

35) Gunderson, L. (1999) Resilience, flexibility and adaptive management; antidotes for spurious certitude?, Conservation Ecology, 3(I) [online] URL: http://www.consecol.org/vol3/issI/art7/; Handmer, J.W., S. Dovers and T.E. Downing (1999) Societal vulnerability to climate change and variability, Mitigation and Adaptation Strategies for Global Change, 4(3-4); Olsson, P., L.H. Gunderson, S.R. Carpenter, P. Ryan, L. Lebel, C. Folke and C.S. Holling (2006) Shooting 
These arrangements are evolving; they can be easily adjusted when it is deemed necessary in order to facilitate effective adaptation (second-order learning). ${ }^{36}$

A Dutch example of a new, integrative arrangement is the Steering Committee South Western Delta, which encompasses three provinces, numerous municipalities, three Water Boards, various national policy departments and implementation organizations. This Committee seeks to facilitate the integration and mutual adjustment of various proposals aimed at realizing local adaptation in the South Western Delta of the Netherlands. Based on a thorough analysis of the physical system of the South Western Delta, local projects are assessed and adjusted to prevent unproductive interferences and stalemate situations.

\section{Public-Private Initiatives and Financial Mechanisms}

Climate change poses substantial challenges to societies, as mentioned before. A wide range of actors will be affected. In most cases the main adaptive responses will come from government agencies. However, in some cases private sector initiatives are most appropriate. For example in tourism areas such as ski resorts, climate change may lead to adaptations by the tourism sector, such as a shift between activities during winter and summer periods. It is presumable that the private sector will take the initiative here, and the public sector's role will be rather limited.

\footnotetext{
the rapids; navigating transitions to adaptive governance of social-ecological systems, Ecology and Society 11(1) [online]: http://www.ecologyandsociety.org/vol11/iss1/art18/.

36) Adger, W.N. (2003) Social capital, collective action and adaptation to climate change, Economic Geography, 79(4): 387-404; Adger, W.N., N.W. Arnell and E.L. Tompkins (2005) Successful adaptation to climate change across scales, Global Environmental Change, 15: 77-86; Arvai, J., G. Bridge, N. Dolsak, R. Franzese, T. Koontz, A. Luginbuhl, P. Robbins, K. Richards, K. Smith Korfmacher, B. Sohngen, J. Tansey and A. Thompson (2006) Adaptive management of the global climate problem; bringing the gap between climate research and climate policy, Climatic Change, 78(I): 217-225; Gunderson, L. (1999) Resilience, flexibility and adaptive management; antidotes for spurious certitude?, Conservation Ecology, 3(I) [online] URL: http://www .consecol.org/vol3/issi/art7/; Handmer, J.W., S. Dovers and T.E. Downing (1999) Societal vulnerability to climate change and variability, Mitigation and Adaptation Strategies for Global Change, 4(3-4); Olsson, P., L.H. Gunderson, S.R. Carpenter, P. Ryan, L. Lebel, C. Folke and C.S. Holling (2006) Shooting the rapids; navigating transitions to adaptive governance of socialecological systems, Ecology and Society II(I): I8 [online]: http://www.ecologyandsociety.org/voliI/ issı/artı8/; Yamin, F., A. Rahman and S. Hup (2005) Vulnerability, adaptation and climate disasters; a conceptual overview, IDS Bulletin, 36(4).
} 
A similar case relates to the agricultural sector, representing the main form of land use in most countries. Among the problems caused by climate change are salinization and periods of drought. The challenge for the agricultural sector is then to adjust the choice of crops or cultivation patterns. The role of the public sector may be larger here, because it is often the natural actor to deal with the infrastructure for the supply of fresh water, although there is no general duty to guarantee the provision of all existing functions and land use with an unlimited amount of fresh water. An entirely different case concerns flood risks threatening large urbanized areas in delta regions such as the Rhine, Thames or Mississippi. Here the public sector will take the lead in flood defense measures and spatial planning in vulnerable zones. Initiatives of private actors will mainly follow from the public sector's actions.

An interesting case is found when there is no clear a priori leadership of the private versus the public sector, and where mixed strategies are called for. An example is the inland water transport sector in river areas like the Rhine and the Mississippi. In these river basins the share of barges in total transport may be up to $50 \%$ of all tons transported. However, climate change may lead to strong fluctuations in water levels, implying that during low water periods ships can only be operated with low capacities, threatening reliability and cost performance of this sector. Here joint efforts of private and public actors are needed. ${ }^{37}$ The carriers are motivated to adopt the type of ship that is less vulnerable to low water periods, for example by using lighter construction materials. The clients of inland water transport are motivated to consider strategies to make them less dependent on water variations by changing their logistical strategies, keeping larger stocks or relocating to places that are less sensitive to climate change. The public sector's role is that of considering an adjustment of water management in the river basin, such as the construction of barrages. But wider policies are also possible, such as the adoption of restrictions on land use to increase the capacity of the land to absorb water, so that fluctuations in water levels become less pronounced. Other important actors that will have to accommodate to climate change are the ports being served by the barges, where port facilities will be adjusted in terms of quantity and quality. The best mix of adjustment strategies is not easy a priori to determine here. There is a clear risk that public and private actors will wait for each other, implying a low level of adaptation.

\footnotetext{
37) Jonkeren, O.; Rietveld, P.; van Ommeren, J. 2007. Climate Change and Inland Waterway Transport: Welfare Effects of Low Water Levels on the river Rhine. Journal of Transport Economics and Policy. 4I (3): 387-4II.
} 
In some domains the public sector may mobilize market forces to stimulate an active role of the private sector. Examples include the introduction of payment systems for freshwater, or subsidies for actors that take measures on their own land to increase its water absorbing capacity. The latter strategy would reduce the need for high-dimensioned public systems to cope with the nuisances of heavy rainfall. Financial incentives may also come from insurance companies that charge high premiums in zones with high flood risks near rivers. These incentives will stimulate appropriate adaptation strategies by developers and residents in such areas. Public instruments e.g. land policy instruments, can be used to facilitate the adaptation to climate change. At least four types of activities can be distinguished that can play a role in creating a financial surplus, the first of which is a change in land use. When the use of land is changed, the market value, i.e. the price, changes as well. A second activity can be to improve the quality of the built environment. In that case an added value is also created in the adjacent parcels of land. Thirdly, a most underestimated activity is to create a shortage in the capacity of building land. This can create huge financial surpluses. Fourthly, other planning activities or policies can also create added value, such as those aimed at restrictions on land use (such as parking, access for cars etc.). In the Netherlands this can be regulated both by spatial planning authorities in the binding legal regulations that go with a spatial plan, and by water authorities in their regulations based on water legislation, for example to forbid more than a certain percentage of paved surface in a certain area to avoid water nuisance and flooding caused by a lack of storage capacity in the soil.

Given the large uncertainties related to climate change, and its long term character, there is a risk that climate change is just ignored in land use decisions. There is a clear role for the public sector here to ensure that reliable information is available to support adequate decision- making. To ensure the necessary flexibility (see table I) in adaptation strategies the public sector may use the instrument of spatial reservations. For example when in an area there is a risk of flooding due to heavy rainfall and there is a limited capacity to store the water, it may be wise to impose restrictions on land use so that in the future-when climate change would lead to an aggravation of the water absorption problem - there would be sufficient space to expand the capacity of water buffers. It is clear that this would impose (invisible) costs on the owners of this land because the opportunities to develop the land are obviously reduced. This would call for a compensation for such land users, but only if they have to take a disproportional burden comparing to other users, because the possibility for compensation is based on the principle of 'egalité devantles 
charges publiques, which is broadly applicable in compensation law. Furthermore, paying too much compensation will be regarded as forbidden state aid within European law. Nevertheless, government action in this respect is needed in order to restore the balance between collective benefits and individual costs. ${ }^{38}$

A last issue concerns the balancing of costs and benefits of adaption measures. In every site development project there are some components that are profitable (like building new houses) and some components that only cost money (like water retention facilities). Arrangements like settlements can contribute to balancing costs and benefits within the project. This is a common approach in project development. Although this approach seems logical and self evident, it is not always so in practice. Settlements become more difficult when they have to be applied between projects and the physical distance between the projects increases. Moreover, in the Dutch Spatial Planning Act some principles are formulated that restrict the application of settlements. The first of which is the Profitability Principle which implies that the provisions should be evident and of some significance. Secondly, there is the Accountability Principle, implying that a causal relation must be in order between the costs and the main aim of the project. Thirdly, the Principal of Proportionality presupposes that every type of land use that profits most from a provision pays most. Settlements are especially used in joint projects between public and private partners.

\section{Conclusion and Discussion}

Climate change has serious consequences for the organization of decisionmaking processes within the spatial planning domain. Especially because its consequences are uncertain, multiple, complex and controversial, the governance of adaptation is a balancing act. In this paper we have elaborated on the various consequences of climate change for spatial planning. We started this paper with the aim of formulating conditions that can facilitate the alignment of climate adaptation with spatial planning. We use the term alignment to indicate that climate change will not lead to direct claims on land use. It is not a new function that needs space. It is much more a changing condition to which existing patterns of land use and activity patterns have to adapt.

38) P.P.J. Driessen and H.F.M.W. van Rijswick (20II). Normative aspects of climate adaptation policies, Climate Law, vol. 2(4), pp. 559-58I. 
An adaptive spatial planning paradigm is based on two ambitions. First it has to satisfy and facilitate the socioeconomic ambitions of its society and secondly it has to meet the new, most likely, but still uncertain climate constraints. A society that is able to meet the climate constraints, creating a safe environment in terms of flood prevention, sufficient fresh water and protection against heat and large amounts of rain, but that is not able to meet the fundamental ambition of socioeconomic vitality, will be in decline. Adaptive spatial planning is thus essentially the art of orchestrating games of mutual gain. This requires innovation in the spatial planning system in the next decades. In this paper we have indicated that some elements of the existing system have to be reconsidered in order to realize adaptive spatial planning. These elements are:

- the legal framework and institutional departure points for spatial planning;

- the interactive organization of planning processes;

- the role of public-private initiatives in adaptation policies and the relevance of financial instruments.

\section{I. The Legal Framework: Compensation and Precaution Principles}

To facilitate the alignment between climate adaptation and spatial planning, new principles have to be established to ensure the climate robustness of planning processes. It seems to us that compensation principles and the precautionary principle can be important yardsticks in the future spatial planning practice. The precaution principle forces new projects to explicitly clarify how their proposals are climate proof. The precaution principle will require short-term investors to incorporate the long-term climate proof ambitions. The compensation principle will support investors to find new ways of land use that can absorb much more rain, are resistant against flooding or combine different functions in such a way that they do not have to pay for the external effects of their project. These legal principles contribute to a modest but intelligent role for the government as legislator in the field of adaptation.

\subsection{Interactive Governance Strategies that Combine Decisiveness and Flexibility}

The search towards governance strategies that meet the apparently contradictory criteria of decisiveness and flexibility seems to be highly difficult. 
However, as we have earlier shown, it is possible to combine these principles. $^{39}$

The principles of decisiveness and flexibility can be applied at different action-levels. It is for example possible to set decisive norms on a more generic level while at the same time leaving room for tailor-made interventions in specific circumstances. In such a situation the norm (in terms of flood risk safety, fresh water availability, retention capacity and so forth) is quite clear, but the way in which it is realized in concrete cases can differ.

The principles can also be applied to a different extent when it comes to different domains. Some issues are too important to allow for much flexibility. In the Dutch context the relevance of strict flood risk safety norms is indisputable. But for other issues, such as fresh water supply for agriculture, the debate is already started as to whether government needs to feel responsible for it. In some domains government will become a more important player while in others its role can evolve towards a more facilitative one.

The third way to combine the principles of decisiveness and flexibility is to apply them depending upon the specific circumstances. By using transparent and authoritative multi-criteria assessments, governments can make legitimate considerations to opt for more compulsory norm-setting in some situations (for example when it comes to realizing residential districts), and for more room to maneuver in other situations (such as zoning camping sites).

\subsection{Public and Private Responsibilities and Financial Instruments}

Climate adaptation is by no means a purely public challenge. When public interests such as flood risks are involved, government will have to play an important role. Only governments can force others to comply or to pay their share (taxation). In many cases however, private interests are foremost. It is of crucial importance for the success of adaptation that private parties should play their own role in the adaptation process. Joint investments combining profit and planet will be the ultimate solution for the problem of climate change. In a period of recovery from a credit crisis this principle will be even more important on both sides. Climate adaptation is essentially a public-private challenge and thus a matter of public and private investments. In this joint effort, it is of crucial importance to balance costs and benefits, between different stakeholders and between common and individual interest.

\footnotetext{
39) Van Buuren, A. \& G.R. Teisman. 20I0. De governance van klimaatadaptatie. Naar een legitieme balans tussen daadkracht en draagvlak. Beleid en Maatschappij. 37 (I): 59-72.
} 